\title{
PENGARUH MEDIASI DARI PERCEIVED RESPONSIBILITY TERHADAP HUBUNGAN ANTARA OBEDIENCE PRESSURE DAN BUDGETARY SLACK
}

\author{
Sakina Nusarifa Tantri \\ Program Studi Akuntansi/Departemen Ekonomika dan Bisnis/Sekolah Vokasi/Universitas Gadjah Mada, Indonesia \\ Email: sakina.tantri@ugm.ac.id
}

\begin{abstract}
ABSTRAK
Penelitian ini bertujuan untuk menguji pengaruh mediasi dari perceived responsibility terhadap hubungan antara obedience pressure dan budgetary slack. Kuesioner didistribusikan melalui sebuah survey yang dilakukan terhadap 100 responden yang tinggal di Indonesia dan terlibat dalam pembuatan rekomendasi anggaran perusahaan. Analisis statistik dilakukan menggunakan SEM. Hasil penelitian ini menunjukkan bahwa obedience pressure memiliki pengaruh positif signifikan terhadap budgetary slack dan berpengaruh negatif terhadap perceived responsibilty, sementara itu perceived responsibility berpengaruh negatif signifikan terhadap budgetary slack. Analisis lebih lanjut yang dilakukan terhadap pengaruh mediasi menghasilkan kesimpulan bahwa perceived responsibilty memediasi secara parsial hubungan antara obedience pressure dan budgetary slack.
\end{abstract}

Kata kunci: budgetary slack, mediasi, obedience pressure, perceived responsibility, SEM.

\section{PENDAHULUAN}

\section{Latar Belakang}

Anggaran merupakan komponen penting yang dibutuhkan oleh organisasi sektor swasta dan juga sektor publik. Pada kedua sektor tersebut, anggaran berfungsi untuk mencerminkan sasaransasaran strategis baik jangka pendek maupun jangka panjang yang dapat dicapai melalui aktivitasaktivitas yang telah ditetapkan guna mencapai tujuan organisasi. Proses pembuatan anggaran pada mulanya dilakukan melaui pendekatan top-down, yaitu rencana dan jumlah anggaran ditetapkan oleh atasan atau pemegang kekuasaan atas anggaran, yang nantinya anggaran tersebut diterima oleh bawahannya untuk dilaksanakan. Dalam pendekatan ini, bawahan tidak memiliki kuasa untuk berpartisipasi dalam pembuatan anggaran, sehingga hanya melakukan apa yang telah disusun di dalam anggaran tersebut. Permasalahan muncul apabila bawahan memiliki lebih banyak informasi daripada atasan sebagai dasar dalam penyusunan anggaran. Akibatnya, bawahan dapat mengalami kesulitan dalam mencapai anggaran. Selain itu, tidak adanya partisipasi anggaran menyebabkan bawahan kurang memiliki motivasi dalam mencapai target-target anggaran (Huda et al., 2014).

Seiring berkembangnya zaman yang ditandai dengan kondisi lingkungan yang semakin kompetitif dan penuh ketidakpastian, pembuatan anggaran semakin mengarah pada pendekatan partisipatif. Young (1985) mendefinisikan participation dalam konteks penganggaran sebagai sebuah proses yang menjelaskan mekanisme bahwa atasan memilih bentuk kontrak kompensasi dan bawahan diperbolehkan untuk memilih nilai spesifik dari setiap parameter di dalam kontrak. Dengan penganggaran partisipatif, seluruh informasi yang diketahui bawahan akan dapat terakomodasi dengan baik dan bawahan memiliki motivasi lebih besar dalam melaksanakan anggaran karena terlibat dalam pembuatannya. Meskipun demikian, penganggaran secara partisipatif ini memiliki dampak bahwa dengan adanya kesempatan bagi bawahan untuk menetapkan parameter, bawahan cenderung menetapkan ukuran yang bersifat menguntungkan.

Penetapan ukuran-ukuran yang menguntungkan ini biasanya berbentuk kelonggaran dalam anggaran atau sering disebut dengan budgetary slack (senjangan anggaran). Anggaran yang dibuat longgar akan menyebabkan anggaran tersebut mudah dicapai sehingga penilaian kinerja berdasarkan anggaran memberikan hasil yang baik. Hal ini sesuai dengan penelitian Damrongsukniwat et al. (2015) yang menyatakan bahwa budgetary slack berhubungan positif dengan ketercapaian anggaran. Anthony dan Govindarajan (2007) menuliskan dalam bukunya bahwa budgetary slack adalah selisih antara anggaran yang ditetapkan dengan anggaran yang sesuai dengan 
estimasi terbaik dari organisasi. Young (1985) menyatakan secara lebih spesifik, bahwa budgetary slack adalah tindakan mengestimasi pendapatan lebih rendah dan memperkirakan biaya lebih tinggi ketika agen diberi kesempatan untuk memilih standar kerja, sehingga informasi yang disajikan kepada atasan menjadi bias.

Menurut Young (1985), agen yang terlibat dalam penyusunan anggaran cenderung melakukan budgetary slack karena mereka memiliki keinginan untuk menghindari risiko. Semakin tinggi risiko yang dihadapi oleh perusahaan, maka semakin tinggi kecenderungan bawahan untuk melakukan budgetary slack. Dunk (1993) juga melakukan penelitian terkait budgetary slack dan menghasilkan kesimpulan yang tidak konsisten dengan penelitian Young (1985), yaitu interaksi antara partisipasi, informasi asimetri, dan budget emphasis berhubungan negatif dengan budgetary slack.

Tidak seperti penelitian-penelitian di atas, terdapat juga penelitian yang menghasilkan bahwa slack bukan berasal dari agen yang memiliki kesempatan untuk berpartisipasi dalam pembuatan anggaran, tetapi justru berasal dari keinginan manajemen tingkat atas yang menekan manajer tingkat bawahnya agar melakukan perintah sesuai dengan permintaannya (Davis et al., 2006 dan Grediani dan Sugiri, 2013).

Davis et al. (2006) mengembangkan penelitian mengenai kerentanan terhadap obedience pressure (tekanan kepatuhan) untuk melakukan budgetary slack pada akuntan manajemen dengan partisipan yang berasal dari Canada dan Amerika Serikat, dan dihasilkan bahwa tekanan kepatuhan mempengaruhi keputusan dalam membuat rekomendasi anggaran. Selain itu, partisipan yang melakukan budgetary slack kurang memiliki tanggung jawab pada diri sendiri untuk mengambil keputusan tersebut, berbeda dengan partisipan yang tidak melakukan budgetary slack, mereka merasa lebih bertanggung jawab atas keputusannya. Di Indonesia, penelitian Davis et al. (2006) dikembangkan oleh Grediani dan Sugiri (2013) menggunakan partisipan mahasiswa. Penelitian tersebut menghasilkan kesimpulan yang sama dengan penelitian sebelumnya, bahwa tekanan kepatuhan mempengaruhi keputusan rekomendasi anggaran.

Pada penelitian kali ini, peneliti mengacu pada penelitian Davis et al. (2006) yang menghubungkan antara stimulus berupa tekanan kepatuhan dengan kenaikan budgetary slack yang diukur menggunakan kenaikan rekomendasi anggaran melalui respon terhadap tekanan sebagai anteseden. Dalam penelitian Davis et al. (2006), dikatakan bahwa tekanan kepatuhan yang tidak layak dari atasan dapat menyebabkan adanya stress-based responsibility shifting dalam diri akuntan manajemen dan memotivasi mereka untuk memberikan rekomendasi awal anggaran yang tidak sesuai dengan kebijakan perusahaan. Dalam hal ini, dapat dikatakan bahwa akuntan manajemen mengalami perubahan persepsi tanggung jawab dikarenakan adanya tekanan dari atasan.

Peneliti ingin melakukan analisis lebih lanjut dan mengembangkan model penelitian Davis et al. (2006) tentang hubungan antara obedience pressure dengan budgetary slack, sekaligus menjawab keterbatasan penelitian tersebut bahwa hubungan sebab-akibat dari model penelitian dan sejauh mana perceived responsibility memediasi hubungan antara obedience pressure dengan budgetary slack belum dapat diidentifikasi (Davis et al., 2006). Saran yang diberikan oleh Davis et al. (2006) terkait hal tersebut adalah menggunakan model mediasi untuk mengevaluasi faktor-faktor yang memediasi pengaruh obedience pressure. Karena sepengetahuan peneliti belum ada penelitian yang menguji hubungan tersebut menggunakan model mediasi, peneliti ingin menguji model Davis et al. (2006) menggunakan model variabel pemediasi untuk menunjukkan hubungan sebab-akibat pada pengaruh obedience pressure terhadap budgetary slack melalui stress response yang berupa perceived responsibility sebagai anteseden.

Hasil penelitian ini memberikan kontribusi terhadap perkembangan teori dan pengetahuan, terutama terkait dengan adanya obedience pressure dan perceived responsibility pada penciptaan budgetary slack. Selain itu, penelitian ini diharapkan memberikan kontribusi terhadap perkembangan teori dan pengetahuan dengan merumuskan model mediasi, yaitu perceived responsibility yang diajukan sebagai variabel pemediasi dalam hubungan antara obedience pressure terhadap budgetary slack, serta berkontribusi terhadap praktik di dunia kerja dengan memberikan pemahaman bahwa konflik etika dan profesional dapat muncul ketika atasan memberikan tekanan kepada individu untuk melakukan hal yang tidak benar. Penulisan karya ini memiliki sitematika yaitu 
latar belakang, dilanjutkan dengan landasan teori, pengembangan hipotesis, metode penelitian, diskusi dan implikasi, dan diakhiri dengan keterbatasan dan saran.

\section{Landasan Teori}

\section{Budgetary Slack}

Slack didefinisikan sebagai total sumber daya yang tersedia untuk sebuah perusahaan dan total kebutuhan untuk mengelola organisasi (Onsi, 1973). Slack merupakan jumlah dimana subordinate melakukan underestimation yang disengaja atas kapabilitas produktif atau overestimation atas cost dan sumber daya perusahaan ketika memilih standar untuk mengevaluasi kinerja mereka (Young, 1985; Collins et al., 1987).

Menurut Onsi (1973), Kennis (1979), Young (1985), Brownell dan McInnes (1986), Dunk dan Perera (1997), dan Yuen (2004), budgetary slack terjadi dalam konteks participative budgeting. Mekanisme partisipasi ada karena subordinate biasanya lebih memiliki banyak informasi yang terkait dengan kondisi lingkungan organisasi, maka dari itu subordinate mengajukan anggaran kepada superior atau tingkat manajemen yang lebih tinggi (bottom-up). Partisipasi memberikan peluang bagi subordinate untuk ikut andil secara langsung dalam penciptaan budgetary slack, sementara partisipasi yang kecil mengurangi peluang tersebut. Menurut Douglas dan Wier (2000), budgetary slack erat kaitannya dengan tindakan yang tidak beretika. Hal ini didukung oleh penelitian Frezatti (2013) yang melakukan studi kasus dan wawancara terkait persepsi mengenai budgetary slack dan menemukan bahwa slack adalah sesuatu yang harus dihindari.

\section{Obedience Pressure}

Obedience theory (Milgram, 1963 dan Milgram, 1974) mengatakan bahwa individu dapat menampilkan perilaku yang bertentangan dengan nilai-nilai dan kepercayaan personal ketika mereka mendapatkan tekanan untuk menaati seseorang yang memiliki kewenangan. Obedience pressure adalah suatu tipe pengaruh sosial yang dihasilkan ketika individu yang memiliki kekuasaan memerintah individu lain untuk melakukan sesuatu (Lord dan DeZoort, 2001). Obedience pressure berasal dari atasan atau superior dan diberikan kepada subordinate-nya dengan tujuan supaya subordinate patuh kepada atasan.
Obedience pressure ditemukan berinteraksi dengan variabel kognitif individual (Trevino, 1986; Blass, 1991), sedangkan penelitian Davis et al. (2006), menyimpulkan bahwa obedience pressure untuk melakukan slack (sebagai variabel independen) mempengaruhi budgetary slack. Obedience pressure atau tekanan kepatuhan dari atasan langsung untuk melakukan slack yang hal ini bertentangan dengan kebijakan perusahaan menyebabkan akuntan manajemen mengalami ethical dillemma. Davis et al. (2006) menemukan bahwa sebagian besar akuntan manajemen melakukan slack dalam anggaran.

Penelitian Davis et al. (2006) yang dilakukan dengan desain eksperimen pada 77 akuntan manajemen menghasilkan bahwa meskipun terdapat persepsi tentang konflik etika, hampir separuh partisipan melanggar kebijakan eksplisit dan melakukan budgetary slack ketika dihadapkan dengan tekanan kepatuhan dari atasan langsung. Penelitian lain terkait dengan tekanan kepatuhan misalnya penelitian yang dilakukan oleh Ponemon (1992), yang menghasilkan bahwa auditor eksternal cenderung melakukan underreport terhadap jam proyek ketika mereka diberi compliance pressure.

Pada intinya, yang menjadi faktor utama mengapa individu cenderung underperform adalah tekanan. Dalam Grediani dan Sugiri (2013) disebutkan bahwa paradigma ketaatan pada kekuasaan menjelaskan bahwa bawahan yang mengalami tekanan kepatuhan dari atasan akan mengalami perubahan psikologis dari seseorang yang berperilaku otonomis menjadi perilaku agen, sehingga perubahan ini menyebabkan seseorang melepaskan diri dari tanggung jawab atas tindakan yang dilakukannya.

\section{Perceived Responsibility}

Anand (2008) mendefinisikan responsibility sebagai tanggung jawab masing-masing anggota korporat atas kewajibannya untuk meyakinkan bahwa mereka memiliki semua informasi yang dibutuhkan untuk membuat keputusan yang tepat atau melaksanakan tugasnya dengan baik. Penelitian terdahulu telah menguji bahwa perceived responsibility berhubungan dengan tindakan memilih keputusan. Salah satu penelitian terkait hal tersebut adalah de Charms (1968) yang menyimpulkan bahwa persepsi tentang keputusan yang dibuat sendiri dan tidak didikte oleh pihak eksternal meningkatkan 
perasaan bahwa tindakan membuat keputusan tersebut disebabkan oleh diri sendiri.

Perceived responsibility adalah tanggung jawab yang dirasakan terkait pembuatan keputusan moral yang sangat tergantung pada peran individu dan dipengaruhi oleh kondisi situasional (Kelley dan Michela, 1980). Perceived responsibility yang lebih besar meningkatkan dampak emosional terhadap suatu peristiwa, sedangkan perceived responsibility yang lebih rendah menyebabkan pembuat keputusan memiliki lebih sedikit dasar untuk membenarkan atau menyalahkan diri sendiri (Weiner, 1980). Sesuai dengan teori obedience yang dikemukakan oleh Milgram (1963) dan Milgram (1974), individu merasionalisasi perilaku tersebut dengan menempatkan tanggung jawab secara penuh kepada sosok yang memiliki kewenangan daripada menerima tanggung jawab individu atas tindakan yang dilakukannya sendiri.

Davis et al. (2006) dan Grediani dan Sugiri (2013) meneliti tentang pengaruh tekanan kepatuhan dan perceived responsibility terhadap budgetary slack menggunakan metode eksperimen. Dalam eksperimen tersebut, partisipan diberi informasi mengenai anggaran tahun-tahun sebelumnya dan meminta partisipan untuk membuat rekomendasi anggaran berdasarkan informasi tersebut. Perlakuan yang diberikan kepada partisipan adalah dengan memberikan tekanan langsung dari atasan untuk merekomendasikan anggaran di atas ketetapan dari CEO dan diberi informasi bahwa insentif karyawan tergantung pada pencapaian anggaran. Hasil penelitian menyebutkan bahwa sebagian besar partisipan memberikan rekomendasi anggaran lebih tinggi daripada ketetapan CEO dikarenakan mereka merasa kurang bertanggungjawab atas rekomendasi anggaran tersebut. Hal ini mengindikasikan bahwa partisipan merekomendasikan anggaran lebih besar dari seharusnya dikarenakan adanya tekanan dan motivasi terkait dengan insentif karyawan. Hasil penelitian ini konsisten dengan model atributif Kelley dan Michela (1980) bahwa motivasi dan informasi mempengaruhi persepsi dan menyebabkan perubahan perilaku.

\section{Pengembangan Hipotesis}

Obedience pressure mengacu pada tekanan yang muncul karena adanya kekuasaan (Hartmann dan Maas, 2010). Obedience pressure biasanya berbentuk tekanan yang diberikan oleh superior kepada subordinate untuk mematuhi perintah superior tersebut. Davis et al. (2006) meneliti tentang pengaruh obedience pressure terhadap perilaku budgetary slack menggunakan metode eksperimen dan berkesimpulan bahwa adanya tekanan yang berasal dari superior untuk menciptakan slack berpengaruh signifikan terhadap budgetary slack yang dilakukan oleh subordinate. Hal ini ditunjukkan dengan hasil penelitian bahwa ketika dihadapkan dengan dilema etika untuk melakukan budgetary slack, akuntan manajemen yang menerima tekanan dari superior atau atasan menetapkan anggaran yang lebih longgar daripada akuntan manajemen yang tidak menerima tekanan dari atasannya. Hal ini dikarenakan akuntan manajemen menghadapi dilema etika. Dengan adanya tekanan dari atasan, akuntan manajemen akan merasa mantap untuk melakukan budgetary slack dan merasa bahwa perbuatan budgetary slack itu bukan sepenuhnya salah dia sendiri, melainkan tanggung jawab atasan yang memberikan tekanan kepadanya. Berbeda dengan akuntan manajemen yang tidak menerima tekanan, mereka mengalami dilema etika tetapi lebih memikirkan bahwa melakukan budgetary slack sama dengan melanggar kebijakan umum perusahaan, sehingga mereka tidak melakukan budgetary slack. Berdasarkan uraian di atas, hipotesis penelitian ini adalah:

$\mathrm{H}_{1}$ : Obedience pressure memiliki pengaruh positif terhadap budgetary slack

Davis et al. (2006) dan Grediani dan Sugiri (2013) menunjukkan bahwa individu yang mendapatkan tekanan kepatuhan membuat keputusan yang tidak sesuai dengan kemauan mereka sendiri, sehingga melarikan diri dari tanggung jawab karena ada individu lain yang memiliki otoritas untuk membuat partisipan melakukan suatu tindakan. Karena adanya otoritas dari pihak lain tersebut, individu cenderung merasa bahwa dirinya kurang bertanggung jawab atas tindakan yang dilakukan. Dengan kata lain, tanggung jawab individu atas rekomendasi anggaran dilimpahkan oleh individu kepada atasan yang memerintahkannya. Semakin besar tekanan yang diberikan oleh atasan, semakin kecil rasa tanggung jawab individu. Oleh karena itu, hipotesis kedua penelitian ini adalah: 
$\mathrm{H}_{2}$ : Obedience pressure memiliki pengaruh negatif terhadap perceived responsibility

Hasil penelitian Davis et al. (2006) dan Grediani dan Sugiri (2013) menyimpulkan bahwa individu yang melanggar kebijakan perusahaan dengan mentaati perintah atasan merasa kurang bertanggung jawab terhadap hasil keputusan mereka, yaitu menaikkan rekomendasi anggaran. Rekomendasi anggaran yang meningkat dilatar belakangi oleh rasa tanggung jawab yang bergeser (shifted) dari individu dikarenakan tanggung jawab yang dimiliki dilimpahkan kepada atasan yang memerintahkannya untuk menaikkan rekomendasi anggaran. Perceived responsibility jawab dikatakan menurun apabila individu merasa kurang bertanggung jawab atas rekomendasi anggaran. Hal ini menyebabkan individu cenderung menuruti atasan untuk melakukan budgetary slack. Dengan kata lain, rasa tanggung jawab yang menurun dari individu akan menimbulkan kecenderungan budgetary slack yang meningkat. Sebaliknya, ketika rasa tanggung jawab individu semakin tinggi, kecenderungan untuk melakukan budgetary slack akan semakin kecil karena individu merasa bertanggung jawab atas keputusan rekomendasi anggaran yang dibuat. Maka dari itu, hipotesis ketiga pada penelitian kali ini adalah:

\section{$\mathrm{H}_{3}$ : Perceived responsibility memiliki pengaruh negatif terhadap budgetary slack}

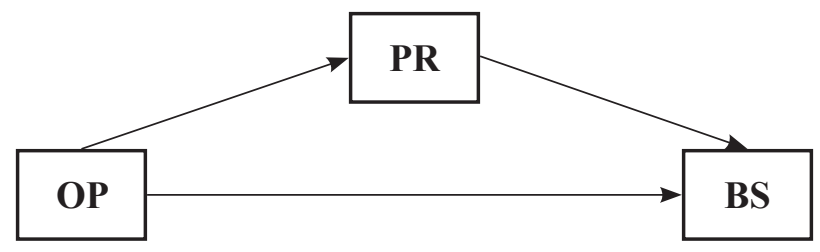

Gambar 1. Model Penelitian

\section{METODE PENELITIAN}

Penelitian ini dirancang untuk menguji pengaruh obedience pressure terhadap budgetary slack dengan perceived responsibility sebagai variabel pemediasi. Data dalam penelitian ini diambil menggunakan survey, yaitu suatu teknik pengumpulan informasi menggunakan sejumlah pertanyaan terstruktur kepada responden. Data dalam penelitian ini dikumpulkan menggunakan kuesioner.

Penelitian ini dilakukan menggunakan kuesioner yang dibagikan kepada responden yaitu karyawan atau manajemen di perusahaan di Indonesia, yang memiliki tugas berkaitan dengan proses penyusunan anggaran. Sampel dalam penelitian ini berasal dari berbagai perusahaan di beberapa provinsi di Indonesia, yaitu Daerah Istimewa Yogyakarta, Daerah Khusus Ibukota Jakarta, Jawa Tengah, Jawa Timur, Sulawesi Selatan, dan Kalimantan Timur. Total responden yang digunakan dalam penelitian ini berjumlah 100. Pertanyaan kuesioner disebar menggunakan metode survey yang dilakukan secara offline dan online. Untuk mengantisipasi kemungkinan bahwa kuesioner tersebut tidak benar-benar diisi oleh responden yang dikehendaki, peneliti memberikan dua poin pertanyaan yang berbunyi "Apakah Anda terlibat dalam proses penyusunan anggaran di perusahaan?" dan "Jelaskan secara singkat tanggung jawab Anda yang berkaitan dengan proses penyusunan anggaran di perusahaan Anda!". Kedua pertanyaan tersebut diajukan untuk mengetahui apakah responden yang mengisi kuesioner tersebut benar-benar pihak yang memiliki peran dalam proses penyusunan anggaran.

\section{Definisi Operasional dan Pengukuran Variabel}

Variabel independen dalam penelitian ini adalah obedience pressure. Obedience pressure adalah suatu tipe pengaruh sosial yang dihasilkan ketika individu yang memiliki kekuasaan memerintah individu lain untuk melakukan sesuatu (Lord dan DeZoort, 2001). Dalam penelitian ini, obedience pressure yang dimaksud adalah tekanan kepatuhan dari atasan untuk melakukan tindakan menyimpang. Data obedience pressure diperoleh melalui kuesioner yang diadopsi dari penelitian Jamilah et al. (2007) yang berisi 5 butir pernyataan dengan skala likert 1-5 (1: sangat tidak setuju, 2: setuju, 3: netral, 4: setuju, 5: sangat setuju). Kuesioner ini digunakan karena sudah pernah diujikan pada sampel di Indonesia dan memiliki nilai reliabilitas dan validitas yang mencukupi.

Variabel dependen pada penelitian ini adalah budgetary slack. Budgetary slack didefinisikan sebagai selisih antara total sumber daya yang tersedia untuk perusahaan dengan total kebutuhan untuk mengelola organisasi (Onsi, 1973), dan merupakan perbedaan antara jumlah anggaran yang diajukan dengan jumlah estimasi yang terbaik (Anthony dan Govindarajan, 2007). Budgetary slack diukur menggunakan kuesioner yang diadaptasi dari penelitian Dunk (1993). Kuesioner ini berisi 6 pernyataan dengan skala 
likert 1-5 (1: sangat tidak setuju, 2: tidak setuju, 3: netral, 4: setuju, 5: sangat setuju).

Variabel pemediasi dalam penelitian ini adalah perceived responsibility. Perceived responsibility adalah tanggung jawab masing-masing anggota korporat atas kewajibannya untuk meyakinkan bahwa mereka memiliki semua informasi yang dibutuhkan untuk membuat keputusan yang tepat atau melaksanakan tugasnya dengan baik (Anand, 2008) yang menekankan pada perasaan atau emosional (Weiner, 1980) dan tergantung pada peran individu yang dipengaruhi oleh kondisi situasional (Kelley dan Michela, 1980).

Perceived responsibility diukur menggunakan skala likert 1-5 (1: sangat tidak setuju, 2: tidak setuju, 3: netral, 4: setuju, 5: sangat setuju) dengan satu pernyataan yang diadopsi dari penelitian Davis et al. (2006) dan digunakan oleh Grediani dan Sugiri (2013). Pernyataan tersebut menunjukkan seberapa besar tanggung jawab yang dirasakan responden atas rekomendasi anggaran yang dibuat di perusahaan.

\section{HASIL DAN PEMBAHASAN}

Sampel yang digunakan dalam penelitian ini adalah karyawan atau manajemen di perusahaan di Indonesia, yang memiliki tugas berkaitan dengan proses penyusunan anggaran di wilayah Daerah Istimewa Yogyakarta, Daerah Khusus Ibukota Jakarta, Jawa Tengah, Jawa Timur, Sulawesi Selatan, dan Kalimantan Timur. Data dikumpulkan dengan menggunakan kuesioner yang disampaikan secara langsung maupun online. Kuesioner dalam bentuk kertas diantarkan langsung ke kantor-kantor dan usaha bisnis yang berada di wilayah Daerah Istimewa Yogyakarta dan Semarang sebanyak 30 eksemplar, sedangkan penyebaran di wilayah-wilayah lain dilakukan menggunakan kuesioner online kepada 90 calon responden. Tingkat respon dalam penelitian ini sebanyak $85 \%$. Dari 102 responden yang mengembalikan kuesioner, terdapat 1 responden yang tidak menjawab pertanyaan secara lengkap, dan 1 responden menyatakan tidak terlibat dalam proses penyusunan anggaran di perusahaan.

\section{Model Pengukuran}

Instrumen yang digunakan dalam penelitian harus merupakan instrumen yang baik dalam mendefinisikan sebuah konstruk. Dengan begitu,
Tabel 1. Karakteristik Responden

\begin{tabular}{|c|c|c|c|}
\hline \multicolumn{2}{|c|}{ Karakteristik } & Jumlah & Persentase \\
\hline \multirow[t]{6}{*}{ Wilayah } & D.I. Yogyakarta & 28 & $28 \%$ \\
\hline & D.K.I. Jakarta & 14 & $14 \%$ \\
\hline & Jawa Tengah & 30 & $30 \%$ \\
\hline & Jawa Timur & 9 & $9 \%$ \\
\hline & Sulawesi Selatan & 12 & $12 \%$ \\
\hline & Kalimantan Timur & 7 & $7 \%$ \\
\hline Jenis & Pria & 39 & $39 \%$ \\
\hline Kelamin & Wanita & 61 & $61 \%$ \\
\hline \multirow[t]{4}{*}{ Usia } & $<30$ tahun & 57 & $57 \%$ \\
\hline & $30-40$ tahun & 29 & $29 \%$ \\
\hline & $40-50$ tahun & 11 & $11 \%$ \\
\hline & $>50$ tahun & 3 & $3 \%$ \\
\hline Pendidikan & SMA/SMK/ & 2 & $2 \%$ \\
\hline \multirow[t]{5}{*}{ Terakhir } & Sederajat & & \\
\hline & Diploma & 13 & $13 \%$ \\
\hline & Sarjana & 63 & $63 \%$ \\
\hline & Magister & 22 & $22 \%$ \\
\hline & Doktor & 0 & $0 \%$ \\
\hline Lama & $>1$ tahun & 11 & $11 \%$ \\
\hline Bekerja & $1-5$ tahun & 41 & $41 \%$ \\
\hline pada & $5-10$ tahun & 35 & $35 \%$ \\
\hline $\begin{array}{l}\text { Posisi } \\
\text { Terakhir }\end{array}$ & $>10$ tahun & 13 & $13 \%$ \\
\hline
\end{tabular}

Sumber: Data Diolah

hasil yang diperoleh dari penggunaan instrumen dalam penelitian ini dapat dikatakan baik pula. Oleh karena itu, perlu dilakukan pengujian terhadap validitas konstruknya (Hartono, 2013). Untuk melakukan pengujian validitas konstruk, digunakan uji validitas konvergen (convergent validity) dan validitas diskriminan (discriminant validity). Untuk melakukan pengujian validitas konvergen dan validitas diskriminan, penelitian ini menggunakan output combined loadings dan cross loadings. Ada dua kriteria yang dapat digunakan untuk menilai apakah instrumen memiliki validitas konvergen, yaitu (1) loading harus di atas 0,70 dan (2) nilai $p$ signifikan $(<0,05)$ (Hair et al., 2013 dalam Sholihin dan Ratmono, 2013).

Nilai pengukuran konstruk obedience pressure telah memenuhi kriteria validitas konvergen karena lebih dari 0,70 dan memiliki nilai $\mathrm{p}<0,001$. Cross loadings variabel obedience pressure ke konstruk lain memiliki nilai yang lebih rendah daripada ke konstruk tersebut. Demikian juga untuk variabel budgetary slack yang memiliki loadings di atas 0,70 kecuali untuk BS4 $(0,664)$ dan nilai $\mathrm{p}<0,001$. Indikator 
BS4 yang bernilai loading di bawah 0,70 dihapus. Hasil dari cross loadings yang lebih rendah dapat juga menjadi indikasi terpenuhinya kriteria validitas diskriminan.

Untuk melakukan pengujian validitas konvergen, penelitian ini juga menggunakan Average Variance Extracted (AVE). Menurut Hair et al. (2013) dalam Sholihin dan Ratmono (2013), instrumen penelitian dinyatakan valid jika memiliki nilai AVE di atas 0,50. Pada penelitian ini, semua nilai AVE lebih dari 0,50 . Hal ini berarti indikator-indikator pengukuran telah memenuhi kriteria dalam pengujian validitas konvergen (convergent validity), yaitu di atas 0,50. Dengan demikian, dapat disimpulkan bahwa ukuran-ukuran yang menyusun konstruk dalam penelitian ini sudah tepat menurut pengujian validitas konvergen karena telah memenuhi kriteria yang ditentukan. Variabel perceived responsibility tidak dapat diuji validitas konstruknya karena pengukurannya menggunakan single indicator.

Pengujian reliabilitas pada penelitian ini dilakukan dengan melihat nilai Cronbach's alpha dan composite reliability. Kriteria yang harus dipenuhi dalam menentukan apakah suatu instrumen reliabel untuk digunakan dalam penelitian adalah nilai Cronbach's alpha dan nilai composite reliability harus lebih besar dari 0,70. Tabel 2 menunjukkan nilai Cronbach's alpha dan composite reliability. Pada penelitian ini, nilai Cronbach's alpha dari semua konstruk telah melebihi 0,6. Selain itu, dilihat dari nilai composite reliability-nya, seluruh konstruk memiliki nilai lebih dari 0,70. Dengan demikian, dapat dikatakan bahwa seluruh konstruk memiliki reliabilitas yang baik. Konstruk perceived responsibility tidak dapat diuji reliabilitasnya karena pengukurannya hanya menggunakan satu indikator.

Tabel 2. Pengujian Validitas dan Reliabilitas Konstruk

\begin{tabular}{cccc}
\hline & AVE & $\begin{array}{c}\text { Cronbach's } \\
\text { Alpha }\end{array}$ & $\begin{array}{c}\text { Composite } \\
\text { Reliability }\end{array}$ \\
\hline $\begin{array}{c}\text { Obedience } \\
\text { Pressure } \\
\begin{array}{c}\text { Budgetary } \\
\text { Slack }\end{array}\end{array}$ & 0,667 & 0,874 & 0,909 \\
$\begin{array}{c}\text { Perceived } \\
\text { Responsibility }\end{array}$ & $\begin{array}{c}\text { (tidak dapat } \\
\text { diuji) }\end{array}$ & & 0,811 \\
\hline
\end{tabular}

\section{Uji Kecocokan Model Penelitian}

Untuk menguji goodness of fit model, digunakan indikator APC, ARS, dan AVIF. Tabel 3 menunjukkan hasil indikator fit yaitu average path coefficient (APC), average R-squared (ARS), dan average variance inflation factor (AVIF). Kedua nilai P untuk APC dan ARS masing-masing adalah $<0,001$ yang berarti signifikan karena kurang dari 0,05 . Sementara itu, nilai AVIF yang sebesar 1,496 menunjukkan bahwa goodness of fit model terpenuhi karena nilainya kurang dari 5.

Tabel 3. Model Fit Indices dan P-values

\begin{tabular}{lll}
\hline & & P-Values \\
\hline APC & 0,492 & $<0,001$ \\
ARS & 0,481 & $<0,001$ \\
AVIF & 1,496 & \\
& Good if $<5$ & \\
\hline
\end{tabular}

\section{Pengujian Hipotesis}

Dalam penelitian ini, pengujian hipotesis dilakukan menggunakan software WarpPLS dengan tujuan mengevaluasi model struktural. obedience pressure berpengaruh positif $(0,42)$ terhadap budgetary slack secara signifikan (ditunjukkan oleh nilai p sebesar $<0,001)$. Obedience pressure berpengaruh negatif $(-0,68)$ dan signifikan $(\mathrm{p}<0,001)$ terhadap perceived responsibility. Sementara itu, pengaruh perceived responsibility terhadap budgetary slack adalah negatif $(-0,38)$ dan signifikan $(\mathrm{p}<0,001)$.

Effect size dapat dikelompokkan menjadi tiga kategori, yaitu lemah $(0,02)$, medium $(0,15)$, dan besar (0,35) (Kock, 2013 dan Hair et al., 2013 dalam Sholihin dan Ratmono, 2013). Effect size pengaruh obedience pressure terhadap budgetary slack adalah sebesar 0,267 yang berarti bahwa obedience pressure memiliki peran cukup penting dalam penciptaan budgetary slack. Peran obedience pressure terhadap perceived responsibility tergolong penting karena memiliki nilai effect size melebihi nilai 0,35 . Sementara itu, perceived responsibility memiliki peran yang cukup penting dalam mempengaruhi budgetary slack. Hal ini ditunjukkan dengan nilai effect size yang termasuk ke dalam golongan menengah $(0,236)$.

Persentase variansi konstruk endogen dapat dijelaskan oleh konstruk yang dihipotesiskan mempengaruhinya. $R$-Squared yang dihasilkan untuk variabel budgetary slack adalah sebesar 0,502, yang 
Tabel 4. Koefisien Jalur

\begin{tabular}{lccc}
\hline & OP & BS & PR \\
\hline OP & & & \\
BS & $0,42(p<0,01)$ & & $-0,38(p<0,01)$ \\
PR & $-0,68(p<0,01)$ & & \\
\hline
\end{tabular}

Tabel 5. Effect Sizes untuk Koefisien Jalur

\begin{tabular}{lccc}
\hline & OP & BS & PR \\
\hline OP & & & \\
BS & 0,267 & & 0,236 \\
PR & 0,459 & & \\
\hline
\end{tabular}

berarti bahwa konstruk tersebut dijelaskan sebesar $50,2 \%$ oleh obedience pressure. Sementara itu, konstruk perceived responsibility dijelaskan sebesar $45,9 \%$ oleh obedience pressure. Tabel $Q$-Squared dapat menjelaskan bahwa model menunjukkan validitas prediktif yang baik ketika nilainya lebih dari nol (Sholihin dan Ratmono, 2013). Nilai Q-Squared untuk budgetary slack dan perceived responsibility lebih dari 0 , sehingga dapat dikatakan bahwa model penelitian menunjukkan validitas prediktif yang baik.

Output full collinearity dapat menjelaskan apakah model bebas dari masalah kolinearitas vertikal, lateral, dan common method bias. Kock (2013) dalam Sholihin dan Ratmono (2013) menyatakan bahwa nilai full collinearity harus kurang dari 3,3. Hasil yang ditampilkan pada tabel 6 kolom VIF menunjukkan bahwa seluruh konstruk memiliki nilai kurang dari 3,3 sehingga dapat dikatakan bahwa model bebas dari masalah kolinearitas vertikal, lateral, dan common method bias.

Tabel 6. Koefisien $R$-Squared, $Q$-Squared, dan VIF

\begin{tabular}{lccc}
\hline & $R$-Squared & $Q$-Squared & VIF \\
\hline OP & & & 1,848 \\
BS & 0,502 & 0,497 & 1,803 \\
PR & 0,459 & 0,465 & 1,847 \\
\hline
\end{tabular}

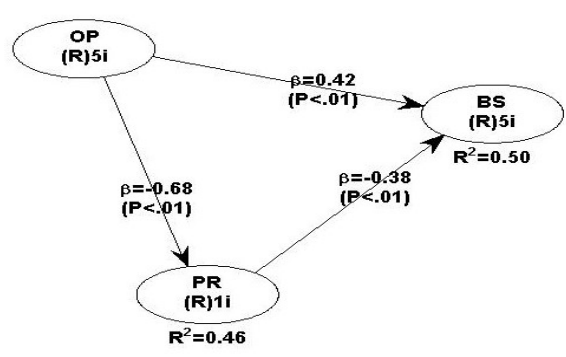

Gambar 2. Model Mediasi
Berdasarkan pengujian hipotesis dengan SEM menggunakan WarpPLS, dihasilkan model mediasi seperti terlihat pada gambar 2 di atas. Hipotesis terdukung apabila nilai p kurang dari 0,05 . Hubungan antara variabel dependen dengan variabel independen dalam penelitian ini dapat dilihat dari nilai koefisien jalur. Tanda pada koefisien jalur menunjukkan positif atau negatifnya hubungan antara variabel independen dan variabel dependen. Berdasarkan tabel 7, dapat dilihat pengaruh obedience pressure terhadap perceived responsibility dan juga pengaruh peprceived responsibility terhadap budgetary slack. Hipotesis 1 yang mengatakan "obedience pressure memiliki pengaruh positif terhadap budgetary slack" terdukung karena nilai koefisien yang dihasilkan adalah 0,42 (positif) dan memiliki nilai $\mathrm{p}<0,01$ sehingga dapat dikatakan bahwa obedience pressure memiliki pengaruh positif signifikan terhadap budgetary slack.

Hipotesis kedua yang berbunyi "obedience pressure memiliki pengaruh negatif terhadap perceived responsibility" juga terdukung. Hal ini dapat dilihat dari angka koefisien yang bertanda negatif $(-0,68)$ dan nilai $p$ yang besarnya $<0,01$. Dengan demikian, dapat dikatakan bahwa obedience pressure memiliki pengaruh negatif signifikan terhadap perceived responsibility.

Hasil pengujian hipotesis ketiga yaitu "perceived responsibility memiliki pengaruh negatif terhadap budgetary slack" juga menunjukkan bahwa hipotesis ketiga ini terdukung. Hal ini ditunjukkan oleh nilai koefisien yang bertanda negatif $(-0,38)$ dengan nilai $\mathrm{p}<0,01$. Oleh karena itu, dapat disimpulkan bahwa perceived responsibility memiliki pengaruh negatif signifikan terhadap budgetary slack.

\section{Tabel 7. Ringkasan Hasil Pengujian Hipotesis}

\begin{tabular}{ccccc}
\hline Hipotesis & $\begin{array}{c}\text { Koefisien } \\
\text { Jalur }\end{array}$ & P-Value & Hasil & Hubungan \\
\hline H1 & 0,42 & $<0,01$ & Terdukung & Positif \\
H2 & $-0,68$ & $<0,01$ & Terdukung & Negatif \\
H3 & $-0,38$ & $<0,01$ & Terdukung & Negatif \\
\hline
\end{tabular}

Penelitian ini mengembangakan model penelitian dari Davis et al. (2006) yang menggunakan metode eksperimen dalam pengumpulan datanya. Metode eksperimen mampu memberikan validitas internal yang baik, tetapi validitas eksternalnya kurang, sehingga penelitian ini memberikan pandangan yang lebih luas 
dari segi teoretis dan menjawab salah satu pertanyaan Davis et al. (2006) bahwa hasil yang disimpulkan dalam eksperimennya belum tentu dapat dibuktikan di dunia kerja yang sebenarnya. Selain itu, penelitian ini menggunakan konteks yang lebih luas daripada penelitian sebelumnya yang mengusung konteks perusahaan yang sebenarnya (Davis et al., 2006 dan Grediani dan Sugiri, 2013). Pertanyaan lain yang dijawab oleh penelitian ini atas penelitian Davis et al. (2006) yaitu pada penelitian tersebut belum dapat diketahui efek mediasi dari perceived responsibility untuk menjembatani hubungan antara variabel obedience pressure dengan budgetary slack. Melalui penelitian ini, kelemahan yang diutarakan pada penelitian Davis et al. (2006) dapat dijawab dengan pengujian hubungan tidak langsung antara obedience pressure terhadap budgetary slack melalui variabel pemediasi perceived responsibility.

Tabel 8. Pengaruh Tidak Langsung

\begin{tabular}{lcc}
\hline & T-Statistics & P-Values \\
\hline $\begin{array}{l}\text { Obedience Pressure } \rightarrow \\
\text { Perceived Responsibility }\end{array}$ & & \\
Obedience Pressure $\rightarrow$ & 0,257 & $<0,01$ \\
Budgetary Slack & & \\
Perceived Responsibility $\rightarrow$ & & \\
Budgetary Slack & & \\
\hline
\end{tabular}

Efek tidak langsung dari pengaruh obedience pressure terhadap budgetary slack memiliki koefisien 0,257 dan nilai $\mathrm{p}<0,001$, yang berarti bahwa efek tidak langsung tersebut signifikan. Namun, perlu diketahui apakah variabel perceived responsibility adalah variabel yang memediasi hubungan antara obedience pressure dengan budgetary slack. Untuk mengetahui hal tersebut, penelitian ini menggunakan metode VAF yaitu dengan prosedur sebagai berikut: (1) pengaruh langsung harus signifikan saat variabel pemediasi belum dimasukkan ke dalam model, (2) setelah variabel pemediasi dimasukkan ke dalam model, maka pengaruh tidak langsung harus signifikan. Setiap jalur harus signifikan untuk memenuhi kondisi ini, (3) melakukan pengujian VAF dengan menghitung VAF $=$ pengaruh tidak langsung/pengaruh total. Pengaruh total adalah pengaruh langsung + pengaruh tidak langsung (Sholihin dan Ratmono, 2013). Pelaksanaan prosedur untuk mengetahui apakah variabel perceived responsibility merupakan variabel pemediasi adalah sebagai berikut. a. Pengaruh langsung saat variabel pemediasi belum dimasukkan

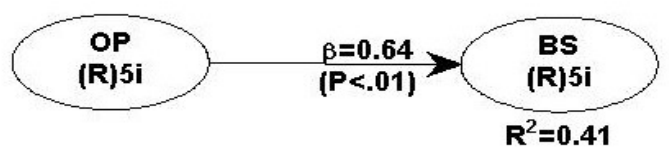

Gambar 3. Pengaruh Langsung

Koefisien jalur dari pengaruh obedience pressure terhadap budgetary slack adalah sebesar 0,64 dengan nilai $\mathrm{p}<0,01$. Hal ini berarti bahwa pengaruh langsung obedience pressure terhadap budgetary slack signifikan.

b. Variabel pemediasi dimasukkan ke dalam model Berdasarkan gambar 2, dapat dikatakan bahwa pengaruh tidak langsung obedience pressure terhadap budgetary slack adalah signifikan $(p<0,01)$ dengan koefisien 0,42 . Gambar 2 juga menunjukkan setiap jalur memiliki nilai $\mathrm{p}<0,01$.

c. Perhitungan VAF

VAF merupakan ukuran yang menunjukkan seberapa besar variabel pemediasi mampu menyerap pengaruh langsung. Jika nilai VAF lebih besar dari $80 \%$, maka variabel pemediasi dapat disebut sebagai full mediation. Jika nilai VAF berkisar di antara 20\%-80\%, maka peran variabel pemediasi disebut dengan partial mediation, tetapi jika nilainya di bawah $20 \%$, maka dinyatakan hampir tidak ada mediasi sama sekali (Hair et al., 2013 dalam Sholihin dan Ratmono, 2013). Berdasarkan tabel 9, diperoleh nilai VAF 0,286 atau $28,6 \%$. Nilai tersebut menunjukkan bahwa variabel perceived responsibility adalah variabel yang berperan sebagai partial mediation.

\section{Tabel 9. Perhitungan VAF}

\begin{tabular}{ll}
\hline Pengaruh tidak langsung (dilihat dari tabel 8) & 0,257 \\
Pengaruh langsung (gambar 3) & 0,64 \\
Pengaruh total =0,257 + 0,64 & 0,897 \\
VAF = pengaruh tidak langsung/pengaruh total & 0,286 \\
\hline
\end{tabular}

\section{KESIMPULAN}

Berdasarkan hasil analisis penelitian, maka beberapa kesimpulan yang dapat diambil dari penelitian ini, antara lain: obedience pressure memiliki pengaruh positif terhadap budgetary slack. Semakin besar tekanan kepatuhan yang didapatkan 
untuk melakukan penyimpangan, semakin besar budgetary slack yang dilakukan. Obedience pressure ditemukan memiliki pengaruh negatif terhadap perceived responsibility. Semakin besar tekanan kepatuhan yang didapatkan dari atasan, semakin kecil rasa tanggung jawab individu yang menerima tekanan tersebut. Sementara itu, perceived responsibility memiliki pengaruh negatif terhadap budgetary slack. Semakin besar rasa tanggung jawab individu, semakin kecil kemungkinan melakukan budgetary slack. Sebaliknya, semakin kecil rasa tanggung jawab, semakin besar kemungkinan individu untuk melakukan budgetary slack.

Implikasi dari penelitian ini dapat ditinjau dari segi teori maupun praktik. Dari segi teoretis, hasil dari penelitian ini dapat memperluas literatur tentang obedience pressure yang berfokus pada hubungannya dengan budgetary slack menggunakan variabel pemediasi perceived responsibility. Dilihat dari segi praktikal, dapat diketahui bahwa ketika seorang atasan dalam suatu manajemen memberikan tekanan kepada bawahannya untuk taat, konflik etika muncul dan menyebabkan bawahan mengalami pergeseran tanggung jawab, dengan kata lain menjadi kurang bertanggung jawab terhadap keputusan yang diambil, yang dalam hal ini adalah menyusun anggaran. Dengan berkurangnya rasa tanggung jawab bawahan, mereka merasa bahwa atasanlah yang memiliki tanggung jawab lebih besar. Hal ini ditandai dengan dilakukannya budgetary slack oleh bawahan yang memiliki peran dalam penyusunan anggaran.

Konsisten dengan teori atribusi dalam Kelley dan Michela (1980), bahwa suatu kondisi yang menyebabkan proses atribusi adalah ketergantungan pada orang lain. Dalam penelitian ini, penyusun anggaran yang membuat rekomendasi anggaran menerima tekanan dari atasan, sehingga menggantungkan keputusan untuk merekomendasikan anggaran yang lebih tinggi daripada seharusnya atas dasar ketergantungan atau dependensi terhadap atasan yang memberikan tekanan tersebut. Dalam proses ini, terdapat persepsi tanggung jawab yang bergeser dari bawahan kepada atasan, dan hal inilah yang mendasari bawahan untuk merasa menggantungkan keputusan kepada atasan. Inilah yang menjadi jawaban dari salah satu kelemahan penelitian Davis et al. (2006) yaitu penelitiannya belum mampu mengidentifikasi adanya faktor yang memediasi hubungan antara stimulus yang diberikan saat eksperimen (obedience pressure) dengan strain outcomes berupa budgetary slack.

\section{Keterbatasan dan Saran}

Setiap penelitian pasti memiliki keterbatasan, dan peneliti menyadari akan adanya keterbatasan dalam penelitian ini. Keterbatasan yang dimaksud antara lain keterbatasan dalam proses pengumpulan sampel. Pengumpulan sampel penelitian ini dilakukan menggunakan metode survey baik secara online maupun offline. Dalam pengumpulan sampel, responden yang mengisi survey secara online hanya dikendalikan melalui pertanyaan mengenai peran dan tanggung jawab responden terkait penyusunan anggaran. Oleh karena itu, kurang dapat dimonitor apakah dalam pengisian survey tersebut responden mengisi dengan benar atau tidak.

Keterbatasan lain dalam penelitian ini adalah hasil yang dihasilkan ternyata menunjukkan bahwa variabel perceived responsibility bukanlah variabel yang mampu memediasi secara penuh. Hal ini membutuhkan kajian lebih mendalam secara literatur dan penelitian lebih lanjut terkait variabel yang mampu memediasi hubungan antara obedience pressure dengan budgetary slack.

Penelitian ini mengembangkan model mediasi antara variabel obedience pressure, perceived responsibility, dan budgetary slack. Penelitian selanjutnya dapat mengembangkan model terkait hubungan antara variabel obedience pressure dan budgetary slack menggunakan variabel pemoderasi atau menambahkan variabel-variabel lain, misalnya budaya organisasi. Budaya organisasi yang cenderung terpusat memungkinkan pembuat anggaran memiliki wewenang yang kecil dalam membuat anggaran, sehingga pembuat anggaran tersebut memiliki tanggung jawab yang relatif kecil dibandingkan dengan perusahaan yang memiliki budaya partisipatif dalam pembuatan anggaran.

Saran lain untuk penelitian selanjutnya adalah dengan memasukkan variabel karakteristik individual, seperti karakter kepribadian berdasarkan Myers-Briggs Type Indicator, atau Dark Triad (Machiavellianism, psychopathy, dan narcissism). Karakteristik individual penting untuk dianalisis karena setiap individu memiliki karakter yang berbeda-beda, sehingga ketika menghadapi tekanan dari atasan, individu dapat menaggapinya secara 
berbeda dan mengambil keputusan yang berbeda pula, khususnya dalam memberikan rekomendasi anggaran.

\section{DAFTAR PUSTAKA}

Anand, S. (2008). Essentials of Corporate Governance. New Jersey: John Wiley \& Sons, Inc.

Anthony, R. N. \& Govindarajan, V. (2007). Management Control System (12th ed). New York: McGraw-Hill.

Blass, T. (1991). Understanding Behavior in The Milgram Obedience Experiment: The Role of Personality, Situations, and Their Interactions. Journal of Personality and Social Psychology, Vol. 60, No. 3, 398-413.

Brownell, P. \& McInnes, M. (1986). Budgetary Participation, Motivation, and Managerial Performance. The Accounting Review, Vol. 61, No. 4, pp. 587-600.

Collins, F., Munter, P, \& Finn, D. W. (1987). The Budgeting Games People Play. The Accounting Review, Vol. 62, No. 1, pp. 29-49.

Damrongsukniwat, P., Kunpanitchakit, D., \& Durongwatana, S. (2015). The Measurement of Budgetary Slack: The Empirical Evidence of Listed Company in Thailand. Journal of Economics, Business and Management, Vol. 3, No. 2 .

Davis, S., DeZoort, F. T., \& Kopp, L. S. (2006). The Effect of Obedience Pressure and Perceived Responsibility on Management Accountants' Creation of Budgetary Slack. Behavioral Research in Accounting, Vol. 18, 2006, pp. 19-35.

Douglas, P. C. \& Wier, B. (2000). Integrating Ethical Dimensions into a Model of Budgetary Slack Creation. Journal of Business Ethics, Vol. 28, No. 3, pp. 267-277.

DeCharms, R. (1968). Personal Causation. New York: Academic Press.

Dunk, A. S. (1993). The Effect of Budget Emphasis and Information Asymmetry on the Relation between Budgetary Participation and Slack. The Accounting Review, Vol. 68, No. 2, pp. 400-410.
Dunk, A. S. \& Perera, H. (1997). The Incidence of Budgetary Slack: A Field Study Exploration. Accounting, Auditing \& Accountability Journal, Vol. 10.

Frezatti, F., Beck, F., \& Da Silva, J. O. (2013). Perceptions About the Creation of Budgetary Slack in a Participatory Budget Process. Journal of Education and Research in Accounting, Vol. 7, No. 4, pp. 322-341.

Grediani, E. \& Sugiri, S. (2013). Pengaruh Tekanan Ketaatan dan Tanggungjawab Persepsian pada Penciptaan Budgetary Slack. Jurnal Akuntansi \& Manajemen, Vol. 24, No. 3, hal. 143-153.

Hartmann, F. G. H. \& Maas, V. S. (2010). Why Business Unit Controllers Create Budget Slack: Involvement in Management, Social Pressure, and Machiavellianism. Behavioral Research in Accounting. Vol. 22, No. 2, pp. 27-49.

Hartono, J. (2013). Pedoman Survei Kuesioner. Yogyakarta: BPFE.

Huda, K., Sinarwati, N. K., \& Herawati, N. T. (2014). Pengaruh Partisipasi Anggaran Terhadap Senjangan Anggaran dengan Budaya Organisasi sebagai Variabel Pemoderasi pada PT. Pos Indonesia (Persero) Singaraja. e-Journal S1 Akuntansi Universitas Pendidikan Ganesha, Vol. 2, No. 1.

Jamilah, S., Fanani, Z., \& Chandrarin, G. (2007). Pengaruh Gender, Tekanan Ketaatan, dan Kompleksitas Tugas terhadap Audit Judgment. Simposium Nasional Akuntansi X. Makassar, Indonesia.

Kelley, H.H. \& Michela, J. L. (1980). Attribution Theory and Research. Annual Reviews. Psychology. 31: 457-501.

Kennis, I. (1979). Effects of Budgetary Goal Characteristics on Managerial Attitudes and Performance. The Accounting Review, Vol. 54, No. 4, pp. 707-721.

Lord, A. T. \& DeZoort, F. T. (2001). The Impact of Commitment and Moral Reasoning on Auditors' Responses to Social Influence Pressure. Accounting, Organizations and Society, Vol. 26, pp. 215-235. 
Milgram, S. (1963). Behavioral Study of Obedience. Journal of Abnormal and Social Psychology 67, 371-78.

Milgram, S. (1974). Obedience to Authority. New York, NY: Harper \& Row.

Onsi, M. (1973). Factor Analysis of Behavioral Variables Affecting Budgetary Slack. The Accounting Review. Vol. 48, No. 3, pp. 535548.

Ponemon, L. A. (1992). Auditor Underreporting of Time and Moral Reasoning: An Experimentallab Study. Contemporary Accounting Research, Vol. 9, pp. 171-189.

Sholihin, M. \& Ratmono, D. (2013). Analisis SEM-PLS dengan WarpPLS 3.0. Yogyakarta: Penerbit ANDI.

Trevino, L. K. (1986). Ethical Decision Making in Organizations: A Person-Situation Interactionist
Model. The Academy of Management Review, Vol. 11, No. 3, pp. 601-617.

Weiner, B. (1980). A Cognitive (Attribution)Emotion-Action Model of Motivated Behavior: An Analysis of Judgments of Help-Giving. Journal of Personality and Social Psychology, 39(2), pp. 186-200.

Young, S. M. (1985). Participative Budgeting: The Effects of Risk Aversion and Asymmetric Information on Budgetary Slack. Journal of Accounting Research, Vol. 23, No. 2, pp. 829842.

Yuen, C. Y. (2004). Goal characteristics, Communication and Reward Systems, and Managerial Propensity to Create Budgetary Slack. Managerial Auditing Journal, Vol. 19 No. 4, pp. 517-532. 